\title{
EFEKTIVITAS PEMBELAJARAN DENGAN PEER ASSESSMENT TERHADAP PRESTASI BELAJAR PADA MATERI TURUNAN DITINJAU DARI KEMANDIRIAN BELAJAR MAHASISWA PENDIDIKAN MATEMATIKA IAIM NU METRO
}

\author{
Eka Fitria Ningsih ${ }^{(1)}$ \\ ${ }^{(1)}$ Program Studi Pendidikan Matematika Institut Agama Islam Ma'arif NU Metro \\ Ekamatika@gmail.com
}

\begin{abstract}
ABSTRAK
Penelitian ini bertujuan untuk mengetahui: (1) Apakah pembelajaran dengan menggunakan peer assessment efektif terhadap prestasi belajar pada materi turunan mahasiswa pendidikan matematika IAIM NU Metro; (2) Manakah yang memiliki prestasi belajar lebih baik antara mahasiswa dengan kemandirian belajar tinggi, sedang dan rendah; (3) Pada pembelajaran dengan menggunakan peer assessment manakah yang memiliki prestasi belajar lebih baik antara mahasiswa dengan kemandirian belajar tinggi, sedang dan rendah. Jenis penelitian ini adalah penelitian komparatif dengan desain faktorial $2 \times 3$. Populasi pada penelitian ini adalah seluruh mahasiswa program studi pendidikan matematika semester 1 Tahun akademik 2014/215. Sampel pada penelitian ini berjumlah 40 mahasiswa yang terdiri dari 20 mahasiswa kelas A sebagai kelas ekperimen dan kelas B sebagai kelas kontrol. Teknik analisis data untuk menguji hipotesis adalah dengan anava dua jalan. Kesimpulan penelitian ini adalah: (1) Pembelajaran dengan menggunakan peer assessment efektif terhadap prestasi belajar pada materi turunan; (2) Mahasiwa dengan kemandirian belajar tinggi memiliki prestasi belajar yang lebih tinggi daripada kemandirian belajar sedang maupun rendah. Sedangkan mahasiwa dengan kemandirian belajar sedang memiliki prestasi belajar yang sama baiknya dengan kemandirian belajar rendah; (3) Dengan pembelajaran peer assessment mahasiswa dengan kemandirian belajar tingggi memiliki prestasi belajar yang lebih baik sedangkan mahasiswa dengan kemandirian belajar sedang memiliki prestasi belajar yang sama baiknya dengan kemandirian belajar rendah.
\end{abstract}

Kata Kunci : peer assessment, belajar, kemandirian, prestasi 


\section{PENDAHULUAN}

Kecakapan berkomunikasi sangat penting untuk dimiliki oleh calon pendidik. Komunikasi yang baik dapat memudahkan proses pembelajaran karena pada hakikatnya pembelajaran merupakan suatu penyampaian informasi (dalam hal ini guru sebagai pendidik) kepada penerima informasi (dalam hal ini siswa sebagai peserta didik). Selain itu, setelah lulus dari perkuliahan mahasiswa akan menjadi salah satu bagian dari masyarakat sesuai profesi yang disandangnya sehingga mereka harus mampu berinteraksi dan bersosialisasi. Oleh karena itu, komunikasi penting untuk dilatihkan kepada mahasiswa. Untuk mengembangkan kemampuan tersebut, perlu dikembangkan sebuah inovasi dalam pembelajaran.

Selain harus dapat berkomunikasi dengan baik, calon pendidik juga perlu memiliki kemampuan untuk memberikan penilaian (Widyawati \& Iswahyudi, 2014). Kemampuan untuk memberikan penilaian kepada peserta didik dapat dilatih dari bangku perkuliahan. Salah satu inovasi pembelajaran yang dapat diterapkan untuk melatih kecakapan berkomunikasi dan kemampuan dalam menilai yakni melalui peer assessment.

Peer assessment adalah sebuah penilaian dimana seorang siswa menilai hasil belajar teman atau siswa lainnya yang berada satu tingkat. Maksud dari satu tingkat adalah jika dua orang atau lebih berada dalam level kelas yang sama. Selain itu, peer assessment dalam penilaian dapat membantu siswa untuk berlatih mengevaluasi dan mengkritisi pekerjaan temannya, kemampuan mengevaluasi ini akan melatih siswa untuk menimbang kriteria yang benar dan salah sesuai dengan prosedur yang telah ditetapkan. Dengan demikian, prestasi belajaranyapun diharapkan dapat meningkat.

Selain pembelajaran yang digunakan di kelas terdapat factor lain yang mempengaruhi prestasi belajar. Salah satu factor tersebut adalah kemandirian belajar. Kemandirian belajar merupakan suatu sikap mental yang ada pada diri peserta didik untuk melakukan sesuatu tanpa bergantung pada orang lain. Hal ini sesuai dengan pendapat Zimmerman (1990) "self-regulated students proactively seek out information when needed and take the necessary step to master it. When they encounter obstacles such as poor study conditions they find a way to succeed". Peserta didik yang memiliki kemandirian belajar yang baik secara aktif akan mencari informasi mengenai langkah yang diperlukan untuk menguasai materi sekalipun kondisinya tidak sesuai mereka akan menemukan cara untuk sukses. Kemadirian belajar merupakan hal yang penting untuk dimiliki peserta didik. Hal ini sesuai dengan pendapat Kramarski et al. (2013) bahwa kemadirian belajar merupakan kompetensi interdisipliner penting yang mengarah untuk meningkatkan pengetahuan pembelajaran dan membantu individu mengatasi tantangan belajar seumur hidup dalam masyarakat. Berdasarkan penelitian Tahar dan Eceng (2006) kemandirian belajar memiliki korelasi positif tehadap hasil belajar.

Pada penelitian ini, peneliti bermaksud meneliti efektivitas peer assessment terhadap prestasi belajar pada materi turunan ditinjau dari kemandirian belajar mahasiswa pendidikan matematika pada materi turunan.

\section{RUMUSANMASALAH}

1. Apakah pembelajaran dengan menggunakan peer assessment efektif terhadap prestasi belajar pada materi turunan mahasiswa pendidikan matematika IAIM NU Metro?

2. Manakah yang memiliki prestasi belajar lebih baik antara mahasiswa dengan kemandirian belajar tinggi, sedang dan rendah?

3. Pada pembelajaran dengan menggunakan peer assessment manakah yang memiliki prestasi belajar lebih baik antara mahasiswa dengan kemandirian belajar tinggi, sedang dan rendah?

\section{LANDASANTEORI}

Menurut Suparno (2007:61) belajar adalah proses mengasimilasikan dan menghubungkan pengalaman atau bahan yang dipelajari dengan pengertian yang sudah dimiliki seseorang sehingga pengertiannya akan berkembang. Kemudian menurut Thobrini dan Malik. (2011:17) belajar adalah proses yang terjadi secara internal di dalam suatu individu dalam usahanya memperoleh hubungan baru baik antara perangsang-perangsang, antara reaksi-reaksi ataupun antara perangsang dan reaksi. Menurut Uno (2006:15) belajar adalah pemerolehan pengalaman baru oleh seseorang dalam bentuk perubahan perilaku yang relatif menetap sebagai akibat adanya proses dalam bentuk interaksi belajar terhadap suatu objek yang ada dalam lingkungan belajar. Suprijono (2013:5) tujuan belajar yang eksplisit diusahakan untuk dicapai dengan tindakan instruksional yang biasanya berbentuk pengetahuan dan keterampilan. Sedangkan tujuan belajar sebagai hasil yang menyertai tujuan belajar instruksional bentuknya berupa kemampuan berfikir kritis dan kreatif, sikap terbuka dan demokratis menerima orang lain dan sebagainya. Berdasarkan beberapa pendapat di atas, penulis memperoleh kesimpulan bahwa belajar adalah proses menghubungkan pengalaman baru yang diperoleh dengan pengalaman yang sudah dimiliki yang terjadi secara internal dari interaksi 
terhadap lingkungan belajar sehingga pengetahuan dan keterampilannya berkembang.

Keberhasilan proses belajar mengajar yang dilakukan guru dapat diukur dari sejauh mana peserta didik memahami materi yang diajarkan guru. Kusnandar (2007:251) mengemukakan bahwa Indikator prestasi belajar adalah ciri penanda ketercapaian kompetensi dasar indikator dalam silabus berfungsi sebagai tanda-tanda yang menunjukkan terjadinya perubahan perilaku pada diri peserta didik. Tanda-tanda ini lebih spesifik dan lebih dapat diamati dalam diri peserta didik, jika serangkaian indikator prestasi belajar sudah tampak pada diri mereka, target kompetensi dasar tersebut sudah terpenuhi atau tercapai. Dari beberapa pendapat di atas, dapat disimpulkan bahwa prestasi belajar adalah hasil yang telah dicapai peserta didik setelah menerima suatu pengetahuan yang diwujudkan dalam bentuk angka atau nilai dan juga perbuatan. Pencapaian prestasi belajar ditandai dengan indikator ketercapaian prestasi belajar yang sudah terpenuhi.

Berdasarkan uraian di atas, dapat disimpulkan bahwa prestasi belajar matematika adalah prestasi belajar yang telah dicapai peserta didik dalam proses pembelajaran yang mencerminkan penguasaan peserta didik terhadap mata pelajaran matematika yang dinyatakan dalam bentuk angka.

Menurut Falchikov (2000: 287) peer assessment didasarkan pada filosofi pembelajaran aktif (Piaget, 1971) dan interaksi antar siswa (Cross, 1981) serta menjadi perwujudan dalam konstruksi sosial (Vygotsky, 1962) yang sering dikatakan sebagai konstruksi bersama atas pengetahuan dalam pembelajaran. Peer assessment dikembangkan untuk meningkatkan aktivitas pembelajaran dan aspek ini umumnya berbentuk rasional untuk mengenalkan penilaian teman sebaya ke dalam pembelajaran. Fungsi pendidikan yang penting dalam peer assessment adalah ketentuan di dalam memberikan umpan balik teman sebaya.

Topping (2009) mendefinisikan peer assessment sebagai sebuah proses dimana seorang individu mempertimbangkan jumlah, level, nilai, kesalahan, kualitas atau kesuksesan terhadap hasil belajar dari teman sebaya. Selanjutnya, Topping (2000) juga menyatakan bahwa peer assessment dapat meningkatkan level umpan balik berupa koreksi, konfirmasi, atau saran. Sedangkan Van Den Berg, Admiraal dan Pilot (Aoun, 2008) menyatakan bahwa peer assessment adalah sebuah penilaian mengenai kualitas yang dilakukan sesama siswa dan memberikan umpan balik satu sama lain. Menurut Deakin Crick dkk (2005), peer assessment melibatkan siswa di dalam penilaian hasil pekerjaan teman yang lainnya. Peer assessment mengacu pada penilaian formatif, karena siswa diminta untuk bertanya kepada teman yang lainnya mengenai pertanyaan yang biasanya ditanyakan kepada gurunya dan menjelaskan kepada yang lainnya menggunakan bahasa yang mudah dimengerti.

Menurut beberapa pendapat tersebut, dapat disimpulkan bahwa peer assessment merupakan suatu bentuk penilaian formatif dimana siswa saling menilai pekerjaan satu sama lain dan memberikan umpan balik berupa koreksi, konfirmasi ataupun saran. Peer assessment merupakan sebuah cara untuk meningkatkan kemampuan kerja yang berhubungan dengan komunikasi lisan dan komunikasi tertulis, membaca, keterampilan dan strategi dalam pembelajaran, pemecahan masalah, pengambilan keputusan, ketergantungan dan tanggung jawab. Oleh karena itu, sering dianjurkan untuk mengimplementasikan pada konteks pendidikan tinggi. Pandangan ini didukung oleh penelitian Ballantyne (Aoun,2008) yang menyatakan bahwa peer assessment dapat memberikan keterampilan yang berguna seumur hidup, karena keterlibatan aktif siswa pada pengalaman dalam penilaian. Ini karena umpan balik formatif dari teman sebaya, khususnya umpan balik yang rinci dan terbuka pada tugas-tugas penilaian yang terkait untuk meningkatkan kepercayaan diri siswa, presentasi, dan kemampuan menilai. Pemberian umpan balik membantu siswa untuk dapat meningkatkan kepercayaan diri mereka didalam proses pembelajaran. Pada akhirnya siswa akan terlibat aktif dalam proses berpikir dan akan memberikan keuntungan didalam melakukan penilaian satu sama lain sehingga mereka akan lebih serius dalam melaksanakannya.

Menurut Wolters et al. (2003) kemandirian belajar merupakan proses konstruksi aktif dimana peserta didik menentukan tujuan untuk belajar dan kemudian berusaha untuk memantau, mengatur dan mengontrol kognisi, motivasi dan perilaku, dibimbing dan dibatasi oleh tujuan mereka dan fiitur kontekstual dalam lingkungan. Menurut Badura dalam Sumarmo (2010) kemadirian belajar merupakan kemampuan mematau perilaku sendiri dan merupakan kerja keras personality manusia. Menurut Mudjiman (2006:1-2) kegitan belajar mandiri diawali dengan adanya kesadaran terdapat suatu masalah kemudian timbul niatan untuk melakukan kegiatan belajar secara sengaja. Kegiatan ini berlangsung dengan atau tanpa bantuan orang lain. Kemampuan belajar mandiri perlu dikembangkan selama peserta didik belajar dalam system pendidikan formal. Hal ini bertujuan agar dapat menjadi bekal yang berguna untuk melakukan pembelajaran sepanjang hidup. Pembelajaran ini penting karena masalah akan 
selalu muncul di dalam perjalanan hidup. Pemecahan secara efektif dan efisien memerlukan kegitan belajar yang berlandasakan pada niat untuk mengatasi masalah dan keterampilan belajar yang memadai (Ningsih \& Iswahyudi, 2014). Indikasi bahwa individu sudah menerapkan kemandirian belajar adalah individu tersebut mengalami perubahan dalam kebiasaan belajar, yaitu dengan cara mengatur dan mengorganisasikan dirinya sedemikian rupa sehingga dapat menentukan tujuan belajar, kebutuhan belajar strategi yang digunakan dalam belajar yang mengarah kepada tercapainya tujuan yang dirumuskan. terdapat enam indikator kemandirian belajar peserta didik yaitu:

a. Ketidaktergantungan terhadap orang lain

b. Memiliki kepercayaan diri

c. Berperilaku disiplin

d. Memiliki rasa tanggung jawab

e. Melakukan kontrol diri.

Instrumen kemandirian belajar yang digunakan untuk mengukur kategori kemandirian belajar peserta didik berupa angket yang disusun berdasarkan indikator kemandirian belajar tersebut. Bentuk skala yang digunakan pada penelitian ini adalah skala Likert. Peserta didik diminta untuk membuat tanda cek $(\sqrt{ })$ pada salah satu dari empat kemungkinan jawaban yang tersedia yaitu "sangat setuju", "setuju","tidak setuju" dan "sangat tidak setuju". Skor yang diperoleh digabungkan dan digunakan untuk mengukur kategori kemandirian belajar tinggi, sedang dan rendah.

\section{HASIL PENELITIAN DAN PEMBAHASAN}

Pembelajaran dengan peer assessment dilaksanakan sebanyak lima kali pertemuan. Setelah mengikuti pembelajaran dengan peer assessment mahasiswa diukur prestasi belajarnya. Tes prestasi belajar diikuti oleh 40 mahasiswa. Pada kelompok eksperimen terdiri dari 20 mahasiswa dan pada kelompok kontrol terdiri dari 20 mahasiswa. Rangkuman hasil perhitungan untuk uji ini disajikan pada tabel berikut.

Tabel 1. Rangkuman Anava Dua Jalan

\begin{tabular}{cccccc} 
Sumber & JK & dk & RK & $\mathrm{F}_{\text {OBS }}$ & $\mathrm{F}_{\alpha}$ \\
\hline $\begin{array}{c}\text { Model } \\
\text { pembel }\end{array}$ & 3945,6 & 1 & 3945, & 75,22 & 4,17 \\
ajaran & 3 & & 63 & & \\
(A) & & & & & \\
Keman & 4288,5 & 2 & 2144, & 46,14 & 3,32 \\
dirian & 9 & & 29 & & \\
Belajar & & & & & \\
(B) & & & & & \\
Interak & 14,57 & 2 & 7,284 & 0,17 & 3,32 \\
si (AB) & & & & & \\
Galat & 1579,9 & 34 & 46,47 & & \\
Total & $\mathbf{9 8 2 8 , 6}$ & $\mathbf{3 9}$ & & & \\
& $\mathbf{9}$ & & & & \\
\hline
\end{tabular}

Dari hasil perhitungan $\mathrm{F}_{\mathrm{obs}}$ untuk $\mathrm{H}_{0 \mathrm{~A}}, \mathrm{H}_{0 \mathrm{~B}}$ dan $\mathrm{H}_{0 \mathrm{AB}}$ yang hasilnya tampak pada table di atas diperoleh keputusan uji bahwa $\mathrm{H}_{0 \mathrm{~A}}$ ditolak, $\mathrm{H}_{0 \mathrm{~B}}$ ditolak dan $\mathrm{H}_{0 \mathrm{AB}}$ diterima. Berdasarkan keputuan uji tersebut diperoleh kesimpulan sebagai berikut.

1) Terdapat perbedaan prestasi belajar antara pembelajaran peer assessment dengan pembelajaran langsung

2) Terdapat perbedaan prestasi belajar antar kategori kemandirian belajar

3) Tidak terdapat interaksi antara model pembelajaran dan kemandirian belajar terhadap prestasi belajar.

Karena $\mathrm{H}_{0 \mathrm{~A}}$ ditolak maka Terdapat perbedaan prestasi belajar antara pembelajaran peer assessment dengan pembelajaran langsung. Berdasarkan perhitungan $\mu_{1}>\mu_{2}$ sehingga dapat disimpulkan pembelajaran dengan peer assessment efektif digunakan pada materi turunan. Melalui pembelajaran dengan peer assessment, mahasiswa terdorong lebih aktif untuk belajar dan mempersiapkan diri karena mereka merasa akan dinilai oleh teman sebayanya. Hal ini sesuai dengan penelitian yang dilakukan oleh Kari Hag dan Peter Hasto tahun 2005 tentang Peer Assessment in Mathematics at Norwegian Technology and Science University. Pada penelitian tersebut diketahui habwa mahasiswa lebih menyukai sesi kedua yang melaksanakan peer assessment dalam pembelajaran. Selain itu, Penelitian yang dilakukan oleh Cheryl Beaver dan Scott Beaver tahun 2011 tentang "The Effect of Peer-Assessment on the Attitudes of Pre-Service Elementary and Middle School Teachers about Writing and Assessing Mathematics". Dalam penelitian tersebut diperoleh bahwa peer assessment dapat membantu mereka meningkatkan pendalaman pengetahuan pada suatu topik pembelajaran, dan mereka akhirnya menjadi pandai menulis kalimat dan paragraf matematika

Selanjutnya pada uji hipotesis kedua diperoleh $\mathrm{H}_{0 \mathrm{~B}}$ ditolak. Untuk melihat lebih lanjut kemandirian belajar mana yang memiliki prestasi belajar yang tinggi maka dilakukan uji lanjut paca anava dengan uji scheffe'.

Sebelum dilakukan komparasi antar kolom terlebih dahulu dihitung rerata marginal dan rerata masingmasing sel. Hasil perhitungannya disajikan pada table berikut.

Tabel 2. Rerata Marginal Pada Masing-masing Sel

\begin{tabular}{ccccc}
\hline $\begin{array}{c}\text { Model } \\
\text { Pembelajar } \\
\text { an }\end{array}$ & \multicolumn{3}{c}{ Kemandirian Belajaar } & Rerata \\
\cline { 2 - 4 } & Tinggi & $\begin{array}{c}\text { Sedan } \\
\text { g }\end{array}$ & $\begin{array}{c}\text { Ren } \\
\text { dah }\end{array}$ & $\begin{array}{c}\text { Margin } \\
\text { al }\end{array}$ \\
\hline $\begin{array}{c}\text { Peer } \\
\text { Assessment }\end{array}$ & 76,8 & 63,7 & 62,8 & 68 \\
Langsung & 62,62 & 57 & 59,1 & 60 \\
Rerata & 69,3 & 60,6 & 61 & 64 \\
Marginal & & & & \\
\hline
\end{tabular}


Selanjutnya untuk rangkuman hasil komparasi ganda antar kolom disajikan pada table berikut.

Tabel 3. Rangkuman Komparasi Ganda

\begin{tabular}{ccc}
\hline $\mathrm{H}_{0}$ & $\mathrm{~F}_{\mathrm{OBS}}$ & $2 \mathrm{~F}_{0,05 ; 2 ; 34}$ \\
\hline$\mu_{\mathrm{s} 1}=\mu_{\mathrm{a}}$ & 10,21 & $(2)(3,32)=6,64$ \\
$\mu_{\mathrm{a} 2}=\mu_{\mathrm{a}}$ & 0,018 & $(2)(3,32)=6,64$ \\
$\mu_{\mathrm{s} 1}=\mu_{\mathrm{a}}$ & 10,72 & (2) $(3,32)=6,64$ \\
\hline
\end{tabular}

Dengan membandingkan $\mathrm{F}_{\text {obs }}$ dengan daerah kritis, terlihat bahwa yang memiliki perbedaan signifikan antara $\mu_{\mathrm{s} 1}$ dengan $\mu_{\mathrm{s} 2}$ dan $\mu_{\mathrm{s} 1}$ dengan $\mu_{\mathrm{r} 2}$. Dengan memperhatikan rerata marginalnya dapat disimpulkan bahwa

a) Peserta didik dengan kemandirian belajar tinggi memiliki prestasi belajar yang lebih baik daripada peserta didik dengan kemandirian belajar sedang.

b) Peserta didik dengan kemandirian belajar tinggi memiliki prestasi belajar yang lebih baik daripada peserta didik dengan kemandirian belajar rendah

c) Peserta didik dengan kemandirian belajar sedang memiliki prestasi belajar yang sama dengan peserta didik dengan kemandirian belajar rendah.

Pelaksanaan peer assessment pada penelitian ini, diawali dari penjelasan secara umum terkait materi turunan. Kemudian, dosen membuat paket-paket soal mengenai turunan. Paket soal tersebut dibagi menjadi tiga kategori yaitu kategori hebat, sangat hebat, hebat sekali. Mahasiswa diminta mengerjakan soal - soal pada tiap kategori dimulai dari kategori hebat, sangat hebat dan kemudian hebat sekali. Mahasiswa dapat berpindah kategori ke kategori yang berada tepat di atasnya dengan syarat mereka telah mengerjakan tiga soal pada tiap kategori. Jawaban yang telah diperoleh, dituliskan dibelakang kartu soal dengan mencantumkan nama berserta hasil yang diperoleh.

Setelah mahasiswa selesai mengerjakan satu soal, mereka mengembalikan soal tersebut ke papan tulis. Soal yang telah dikerjakan oleh seorang mahasiswa dapat diambil oleh mahasiswa lain. Mahasiwa yang memperoleh soal yang sama kemudian mencari alternatif jawaban dari soal tersebut dan membandingkannya dengan hasil yang dituliskan oleh kawannya. Apabila hasil yang diperoleh tidak sama, maka jawaban tersebut dikonsultasikan dan dibahas secara bersama-sama oleh pihak yang bersangkutan. Disinilah letak penilaian teman sejawat atau peer assessment. Dengan mengcross cek jawaban, siswa dapat saling bertukar pikiran dan mengungkapkan ide-ide atau alur jawaban yang digunakan untuk menyelesaikan perosalan tersebut.
Kegiatan menjelaskan jawaban yang diperoleh dapat meningkatkan kemampuan mahasiswa dalam hal komunikasi. Mahasiswa lebih terbuka dengan kawannya dan terbiasa untuk menyampaikan gagasannya. Hal ini membuat mahasiswa lebih mengingat materi dan memahaminya secara mendalam karena mereka sendiri menjelaskannya kepada kawannya. Kemampuan inilah yang menyebabkan prestasi belajar matematika dapat meningkat melalui peer assessment.

Pada pembelajaran dengan peer assessment mahasiswa dengan kemandirian belajar tinggi memiliki prestasi belajar yang lebih tinggi daripada mahasiswa dengan kemandirian belajar sedang maupun rendah. Sedangkan mahasiswa dengan kemandirian belajar sedang memiliki prestasi belajar yang sama baiknya dengan kemandirian belajar rendah. Mahasiswa dengan kemandirian belajar sedang melalui pemebelajaran peer assessment mereka dapat membandingkan jawaban mereka dengan jawaban yang ada. Sedangkan pada mahasiswa dengan kemandirian belajar rendah melalui pembelajaran peer assessment mereka terbuka untuk bertanya kepada kawannya yang telah mengerjakan soal terebut. Dengan penjelasan dan dorongan tersebut itulah yang diduga menjadikan prestasi belajar mereka sama baiknya dengan kemandirian belajar sedang.

\section{SIMPULAN}

Berdasarkan analisis uji hipotesis diperoleh kesimpulan penelitian sebagai berikut.

1. Pembelajaran dengan menggunakan peer assessment efektif terhadap prestasi belajar pada materi turunan mahasiswa pendidikan IAIM NU Metro matematika

2. Mahasiwa dengan kemandirian belajar tinggi memiliki prestasi belajar yang lebih tinggi daripada kemandirian belajar sedang maupun rendah. Sedangkan mahasiwa dengan kemandirian belajar sedang memiliki prestasi belajar yang sama baiknya dengan kemandirian belajar rendah.

3. Pada pembelajaran dengan peer assessment mahasiswa dengan kemandirian belajar tingggi memiliki prestasi belajar yang lebih baik sedangkan mahasiswa dengan kemandirian belajar sedang memiliki prestasi belajar yang sama baiknya dengan kemandirian belajar rendah. 


\section{DAFTAR PUSTAKA}

Aoun, C. 2008. Peer Assessment and learning outcomes: Product Deficiency or Prosess Defectiveness?. Diakses dari http://w ww.iaea2008cabredgeassessment.org.uk/ca/di gitalassets/180447_Aoun.pdf.

Beaver, Cheryl and Scott. 2011. The Effect of PeerAssessment on the Attitudes of Pre-Service Elementary and Middle School Teachers about Writing and Assessing Mathematics. IUMPST: The Journal. 5 : 1-14.

Deakin-Crick, R., Lawson, H., Sebba, J., Harlen, W., and Yu, G. 2005. Research Evidence of the Impact on Students of Self and PeerAssesment. London: University of London.

Falchikov, N. and Goldfinch, J. 2000. Student Peer Assessment In Higher Education: A Meta_Analysis Compating Peer And Teacher Marks. Review of Educational Research. 70(3) : 287-322.

Kramarski, B., Narciss, S., Desoete, A., Perry, N. \& Bannert, M. 2013. New Perspectives on Integrating Self-Regulated Learning at School. Education Research International. Vol. 2013, Article ID 498214.

Kusnandar. 2007. Guru Profesional Edisi Revisi. Jakarta: Rajagrafindo Persada.

Lie, Yuen Lim and Angelique, Lisa. 2003. Implementing Effective Peer Assessment. CDTL Brief National University of Singapure Journal. Volume 3 No. 3.

Mudjiman, H. 2006. Belajar Mandiri. Surakarta: UNS Press.

Ningsih, E. F., \& Iswahyudi, G. (2014). Eksperimentasi Model Pembelajaran Kooperatif Tipe Team Assisted Individualization (TAI) Dengan Metode Snowball Drilling Terhadap Prestasi Belajar Matematika Ditinjau Dari Kemandirian Belajar. Jurnal Pembelajaran Matematika, 2(7).

Purwanto, B. 2012. Eksperimentasi Model Pembelajaran Kooperatif Tipe Think-TalkWrite (TTW) dan Tipe Think-Pair-Share (TPS) Pada Materi Statistika Ditinjau dari Kemadirian Belajar Siswa SMA di Kabupaten Madiun. Tesis UNS. Tidak diterbitkan.
Spiller, D. 2012. Assessment Matters : Self Assessment and Peer Assessment. Waikato : University of Waikato.

Sumarmo, U. 2010. Kemadirian Belajar: Apa, Mengapa, dan Bagaimana Dikembangkan Pada Peserta Didik. http://math.sps.upi.edu. Diunduh pada 24 Sepetember 2013 .

Suparno, P. 2007. Filsafat Konstruktivisme Dalam Pendidikan. Yogyakarta: Kanisius.

Suprijono, A. 2013. Cooperative Learning Teori \& Aplikasi PAIKEM. Yogyakarta: Pustaka Pelajar.

Tahar, I. \& Enceng. Hubungan Kemandirian Belajar dan Hasil Belajar pada Pendidikan Jarak Jauh. Jurnal Pendidikan Terbuka dan Jarak Jauh. Vol. 7 No. 2. pp: 91-101

Thobroni, M. \& Malik, A. 2011. Belajar dan Pembelajaran. Yogyakarta: Ar-Ruz Media.

Topping, K. J. 2009. Peer Assessment. Theory Into Practice. 48: 20-27.

Topping, K. J., Smith, E. F., Swanson, L., Elliot, A. 2000. Formative Peer Assessment of Academic Writing Between Postgraduate Students. Assessment and Evaluation in Higher Education. 25 (2) : 149-169.

Uno, H.B. 2012. Teori Motivasi \& Pengukurannya. Jakarta: Bumi Aksara.

Widyawati, S., \& Iswahyudi, G. (2014). Eksperimentasi Model Pembelajaran Kooperatif Tipe Two Stay Two Stray (Tsts) Dan Numbered Heads Together (Nht) Ditinjau Dari Kecerdasan Majemuk Peserta Didik. Jurnal Pembelajaran Matematika, 2(9).

Wolters, C., Pintrich, P., \& Karabenick, S. 2003. Assessing Academic Self-Regulated Learning. Paper prepared for the Conference on Indicators of Positive Development: Definitions, Measures, and Prospective Validity. Sponsored by Child Trends, National Institutes of Health. 
